that the origin of the slump and of the graded bed which overlies it have something in common. Their close association suggests that the sliding of a mass of sediments caused the water to become muddy and that shortly afterwards the cloud of sediment settled on the slump. Or an earthquake set the muds moving and also disturbed the sediments on the sea floor. In the only case, however, where the point of origin of a slump has been described, the graded bed occurs only over the slump and does not extend on to the sea floor above its point of origin.

It is clear, therefore, that a given slump bed was formed at a time between the deposition of the underlying sediments and that of the overlying sediments; in this sense the slumps are contemporaneous with sedimentation. Further, since both the overlying and underlying sediments are admitted to be of marine origin, it would be surprising if the slumps are not also of that origin. That they are subaqueous is proved by the deposition upon them of the graded bed forming the base of the overlying sediments; it is also evident that the top of the slump was the actual floor of the sea when the sedimentary grains of the graded bed began to shower down upon it.

Examination of a slump will usually reveal that pieces of included sediments lie in it at all angles, and not uncommonly overturned or even recumbent folds have been truncated at the base of the graded bed. The slump beds have therefore acquired their structures before the overlying beds were laid down upon them.

It would be of great interest if anyone can suggest any way of producing these manifold structures in muds on the sea floor except by sliding.

The Sedgwick Museum,

O. T. JONES. CAMBRIDGE.

6th March, 1953.

\title{
ACCURACY IN GEOLOGICAL LOCALITIES
}

Str,--In this Magazine (Ixxxix, 152) A. M. Davies sets right Cossman's view by saying that the interesting Miocene gastropod Pereiraia gervaisi is found in Slovenia and not in Ukraina. Ivandel or correctly Ivandol $\left(45^{\circ} 48^{\prime} 48^{\prime \prime}, 15^{\circ} 19^{\prime} 20^{\prime \prime}\right.$ E. Greenwich), however, should not be retained in the geological literature, as the locality of the gastropod, for the valley (one mile long and without settlements) is little known even in Slovenia. There are some more localities where this gastropod has been found, as for instance: Stara vas, Zgornje Vrhpolje, Ṡmarje, Orehovica, Cerov log, all of them together with Ivandol are near St. Jernej. In Slovene geological literature St. Jernej is indicated as the locality for this gastropod, and it would seem more appropriate to use it in the foreign literature, too.

Inst, of Geol. and Paleont., UNIVERSITY OF LJUBLJANA.

Anton Ramovšs. 15th March, 1953.

\section{GRAVITY MEASUREMENTS OVER THE NORTHERN PENNINES}

SIR,-The announcement by J. Hospers and P. L. Willmore of the discovery of a closed area of negative Bouguer anomalies in and around Upper Weardale and the preliminary account of more detailed work by M. H. P. Bott and D. Masson-Smith (Geol. Mag., xc, 117-126, and 127-130) are both most welcome. There will, I am sure, be general agreement with the authors that the field of negative anomalies is probably the expression of the existence of a buried granite mass. But not everyone will so readily agree with the next step taken by the authors, namely that the "Weardale granite "-assuming it to be real-was the source of the mineralization of the area. Taking this step precludes the possibility that the "granite" may be pre-Carboniferous, 
a possibility that must not be allowed to go by default. Indeed, to my mind, the alternative of a Caledonian granite would seem to raise fewer difficulties and to be more harmoniously in keeping with the geological environment. A Pre-Cambrian granite might also do, but would probably lie too deep to be consistent with the marginal gradients of the negative field. I am, of course, acutely aware of the geochemical enigma presented by the ore deposits, but the mystery is in no way resolved by the assumption of a Hercynian or Tertiary granite. A Hercynian granite under Weardale would be completely out of its appropriate tectonic setting, while a Tertiary granite would be expected to have an attendant dyke swarm, rather than a unique metallogenic episode sandwiched in time between itself and the solitary Cleveland dyke.

On the other hand, equating the "granite" with a supposed granitic source for the ore deposits implies that the original roof has remained intact and essentially undisturbed. From this implication Bott and Masson-Smith infer that the "granite" could have been emplaced only as a magma that stoped its way up. If it could be shown to be justified, this conclusion would obviously be of great significance. But it is not clear to me how a mass deficiency in the crustal column concerned-estimated at $5 \sim 7 \times 10^{17} \mathrm{gm}$. by Bott and Masson-Smith from the negative anomalies-could result from stoping. Being only the mechanical displacement of denser material at higher levels by lighter material from depth, stoping involves neither loss nor gain of mass.

The real point at issue is whether or not a slight change in the vertical distribution of density would suffice to account for the negative anomalies. It is to be hoped that Messrs. Bott and Masson-Smith will deal rigorously with this question in the more detailed publication to which we look forward. It may well be that their final results will turn out to be inconsistent with the stoping hypothesis.

\section{Grant InSTITUte of Geology, UNIVERSTTY OF EDINBURGH. 11th April, 1953.}

Arthur Holmes.

SIR,-We will attempt to answer the points in Professor Holmes's letter. (1) The Association of Intrusion and Mineralization

Professor Dunham (1934) suggested, by analogy, that the Alston Block mineralization originated from a sub-Pennine granitic or granodioritic magma. He indicated that such a theory alone explained the zonal arrangement of the mineralization, but no such exposed igneous body was known. From quite other evidence we are confident that there is an intrusion. Furthermore the genetic association of the mineralization and the "Weardale granite " is presumed from the close correlation between the outer boundary of Dunham's fluorite zone and the gravity anomaly, a correlation which has been further enhanced by more recent gravity survey over the Cross Fell hills. It seems unlikely that such a correlation is fortuitous.

A further line of evidence has recently been drawn to our attention by Professor Dunham. The high rank of coal (Fuel Survey, 1945) in West Durham around Consett decreases to the north, east, and south. The coal of highest rank is found over the eastern part of the negative anomaly, and the rank falls off where the anomaly disappears, reaching its lowest north of the line from Dinnington to Hartley. We are not aware of any evidence to indicate that this is an effect of varying depth of maximum burial. Moreover, the variation of rank between areas is greater than the vertical variation within the areas. Again in view of the correlation between gravity anomaly and chemical data, the suggestion of slight thermal metamorphism is attractive. If this be so the age of the intrusion is post Coal Measures (too late for the removal by erosion of a basic front). Perhaps a Hercynian (or later) "granite" under Weardale will not seem so anomalous when we know more of the deep structure of the Pennines, although certainly the Alston Block was structurally defined in the Tournaisian. 
However, if as Professor Holmes suggests, the granite be Caledonian and its cover were removed before the Carboniferous was deposited it would be difficult for our gravity data alone to distinguish the mode of origin of the granite.

\section{(2) The Estimation of Mass Deficiency}

The deficiency of mass was estimated by integrating the anomaly over a limited area. The total mass deficiency in a crustal column, relative to a neighbouring column, will be zero if $(a)$ the crustal structure were originally homogeneous; $(b)$ there were no change in density of the "granite", nor of the hypothetical stoped mass, during emplacement ; $(c)$ there were no possibility of outflow at depth ; $(d)$ there had been no subsequent doming. If the gravity anomalies from surrounding geological features were negligible, then integrating the anomaly to infinity over a plane surface will give a zero estimate. By finitely limiting the bounds of integration, we limit the depth to which the estimate applies. A near surface mass deficiency will give a sharp and well defined negative anomaly, while an equal surplus of mass at depth will give a broader and shallower positive anomaly. When vertically combined, the estimate obtained by summing the central negative anomaly alone will give an underestimate of the deficiency of mass. Therefore our conclusion does not depend on detecting the presence of stoped material at depth. The deficiency of mass in the upper crust under Weardale is certain, and our estimate may be low. That it is due to direct density contrast with a steep boundary in places follows from the Bouguer gradients. Such a mass deficiency could not be compensated by an equivalent mass surplus as a basic front immediately above and around.

A theoretical discussion of granites and their gravity anomalies is the subject of a paper already submitted to this journal, and field investigations of this problem are continuing.

THE SEDGwick MuSEum,

M. H. P. BotT.

D. Masson-Smith.

CAMBridge.

24th April, 1953.

REFERENCES

DunhaM, K. C., 1934. The genesis of the North Pennine ore deposits. Quart. Journ. Geol. Soc., xc, 689-720.

MinistrY OF FUEL AND POWER, 1945. Durham Coalfield Regional Survey Report. (Northern " A " region.) H.M. Stationery Office.

Northumberland and Cumberland Regional Survey Report. (Northern "B" region.) H.M. Stationery Office.

\section{LUDLOVIAN RESEARCH GROUP}

SIR,--Some of your readers may be interested to hear of the recent formation of a Ludlovian Research Group. The aim of the group is to encourage closer co-operation between geologists who are working on the problems of the Ludlovian rocks. An inaugural meeting was held at Birmingham University from the 24th to the 26th September, 1952, and fifteen geologists were present. Exhibits from various areas were studied and discussions took place on many topics, including the following:--Ludlovian correlation and classification, the Siluro-Devonian boundary, the Wenlock-Ludlow boundary, the sedimentary petrology and palaeontology of the Ludlovian, and the compilation of an annotated bibliography. A typescript bulletin will be published periodically for limited circulation amongst interested workers ; it is intended to contain information from members on mapping and research progress, interesting localities, museum collections, new techniques, recent literature, etc. The 1953 meeting of the group will take the form of a field excursion around the Welsh Borderland areas of Ludlovian 